\title{
Additive effect of cow dung slurry and cellulolytic bacterial inoculation on humic fractions during composting of municipal solid waste
}

\author{
Mansi Rastogi ${ }^{1}$ (D) $\cdot$ Meenakshi Nandal ${ }^{1} \cdot$ Lata Nain $^{2}$
}

Received: 11 December 2017 / Accepted: 9 June 2019 / Published online: 14 June 2019

(c) The Author(s) 2019

\begin{abstract}
Purpose The work aimed to investigate the effect of cow dung and cellulolytic bacteria on humic characteristics during municipal solid waste composting. Four Bacillus isolates (B. subtilis, B. tequilensis, B. venezuelans and B. amyloliquefaciens) sourced from dumpsite soil were formulated as consortium for the study.

Methods Four treatments were considered with addition of bulking agents (ratio 1:7:6) to $15 \mathrm{~kg} \mathrm{MSW}$. Treatment $\mathrm{Cs}_{1}$ (control): only MSW, $\mathrm{Cs}_{2}$ : MSW + cellulolytic bacterial inoculum @ $5 \mathrm{ml}\left(2 \times 10^{9} \mathrm{CFU} \mathrm{ml}^{-1}\right) ; \mathrm{Cs}_{3}-\mathrm{MSW}+$ cow dung slurry @ $1 \mathrm{~kg}(1: 100$ based on wet weight $)$ and $\mathrm{Cs}_{4}-\mathrm{MSW}+$ cellulolytic bacterial inoculum @ $5 \mathrm{ml}\left(2 \times 10^{9} \mathrm{CFU} \mathrm{ml}^{-1}\right)+$ cow dung slurry@ $1 \mathrm{~kg}$ (diluted 1:100 based on wet weight). The analyses of humic acids were done by elemental analyzer, UV and Fourier transform infrared spectroscopy during 90 days of composting.

Results MSW amended with consortia of effective microorganisms and cow dung slurry projected highest humification degree at $82.4 \%(P<0.01)$. Highest temperature $\left(63{ }^{\circ} \mathrm{C}\right)$ was recorded in the treatment $\mathrm{Cs}_{4}$ during composting. The data corresponded to an increase in $\mathrm{H} / \mathrm{C}$ ratio $(0.9 \%)$ with a decrease in $\mathrm{C} / \mathrm{N}(14.8 \%)$ and $\mathrm{O} / \mathrm{C}$ ratio $(0.5 \%)$. In addition, most stabilized values for $E_{4} / E_{6}$ ratio (4.1) and $E_{2} / E_{3}$ ratio (2.1) were observed in $\mathrm{Cs}_{4}$. The humification indices manifest positive regression values $(F(4,1)=0.007 ; P<0.01)$ and $99 \%$ significant model.

Conclusion In the study, bio-augmentation (bacterial consortia and cow dung slurry) to MSW composting facilitates early maturity compared to other inoculated/uninoculated treatments. The result substantiates the effect of temperature on the humification rate of composting.
\end{abstract}

Keywords Municipal solid waste $\cdot$ Composting $\cdot$ Cellulolytic bacteria $\cdot$ Humic acids $\cdot$ Cow dung $\cdot$ Spectroscopy

\section{Introduction}

Escalated urbanization and development have modified the framework of cities in India. Pressure on the resources and infrastructural services has intensified due to a constant increase in urban migration. Migrants generate immense municipal solid waste (MSW) on a day-to-day basis; however, the chunk of land available limits the treatment and safe disposal of such waste (Joshi and Ahmed 2016). A major part of these wastes in India consists of degradable organic material (50-55\%). We can recycle and dispose

Mansi Rastogi

rastogimansi86@gmail.com

1 Department of Environmental Sciences, Maharshi Dayanand University, Rohtak, India

2 Division of Microbiology, Indian Agricultural Research Institute, New Delhi 110012, India them through the economic and ecofriendly technique of composting (Annepu 2012). In composting, the organic matter humidifies into a stable, organic humic product through sequential microbial activities (Pare et al. 1998). The application of a humified product (humus) improves soil texture by augmenting the micro-nutrient deficiencies (Rastogi and Nandal 2018).

Extensive research by various organizations in India is yet to explore the key issue of improving process efficiency. Two main factors identified for influencing the efficacy of process are $\mathrm{C} / \mathrm{N}$ ratio (18) and temperature. Furthermore, additives in form of effective microbes (EMs) or cow dung (a low-cost and available bio-resource) had accelerated the waste treatment (Adegunloye et al. 2007). Diverse microflora (bacilli, lactobacilli, fungi, and yeasts) enter the compost matrix through these additives. It results in a series of microbial oxidation reactions and raised process temperature. This intensified the process of 
composting and enhanced the waste degradation rate. Several researchers followed the above-mentioned approach for MSW composting (Manu et al. 2016; Varma et al. 2017; Nakasaki and Hirai 2017; Voberkova et al. 2017).

Compost fertility defines the quality of product by assessing a stable fraction of residue, humic substance (HS). They are stable heterogeneous organic compounds of humus with a high molecular weight (Smidt et al. 2008). HS enhances crop fertility and productivity by balancing the soil nutrients (Scotti et al. 2015). The three main components of humic substances are humic acid (HA), fulvic acid (FA) and non-humic fractions. At the latter stage of compost, HS undergoes structural and chemical changes that correspond to compost maturity. Evaluation of HS chemistry is essential to assess compost quality and substantiate stability and maturity. Former term defines the rate of biological decomposition during the composting process (Barren et al. 2006), evaluated by determining the humification index (HA:FA) of the compost. The latter verifies the suitability of compost for crops by measuring the ratio of carbon in total humic matter and humin (DeNobili and Petrussi 1988). Various spectral techniques are currently in practice to characterize HS chemistry, such as elemental analysis. It determines the elemental composition and structural changes in HS during composting (Adani et al. 2006). Fourier transform infrared (FTIR) and UV spectroscopy are other nondestructive methods to assess the chemical complexity of the HS (Leal et al. 2015). The derived peaks or UV absorption spectra $\left(E_{2} / E_{3}\right.$ and $\left.E_{4} / E_{6}\right)$ for $\mathrm{HS}$ denoted humidified aromatic material in the composted material (Chen et al. 1977).

The study investigated MSW dumped on an open waste disposal site near Sunaria village at Rohtak (a city in India). The site is under development to set up an engineered sanitary landfill facility. Landfilling with non-recyclable waste stays restricted under Schedule II of Indian MSW Rules, 2000. Conventional landfilling restrains sustainable waste management and generate toxic emissions. It may contaminate soil and groundwater through leaching as well. Composting seems to be a good pretreatment method in case of landfilling, to stabilize the MSW and reduce harmful emissions (Mahar et al. 2009). In addition, inoculation of effective microbes or supplements to waste material showed positive results. Composting with exclusive addition of cellulolytic bacteria and cow dung to MSW has been unreported. Thus, the passive bin-composting study monitored MSW, for the effect of inoculations and/or cow dung slurry on the HS. We studied the HS chemistry using elemental analysis, UV and Fourier transform infrared (FTIR) spectroscopy. Lastly, we compared the HS profiles to validate its authenticity as a maturity marker.

\section{Materials and methodology}

Each treatment bin $(1.5 \mathrm{~m} \times 0.6 \mathrm{~m})$ with 40 circular holes (dia-50 $\mathrm{mm}$ ) and perforated PVC pipe (dia-38 mm) was packed with $15 \mathrm{~kg}$ MSW (Fig. 1). Bulking agents (sawdust, fresh leaves and dry brown twigs, grass) were added in all the treatments in ratio $(1: 7: 6)$. We developed a potent cellulolytic consortium [Bacillus subtilis $(2.0 \mathrm{ml})$, $B$. tequilensis $(1.0 \mathrm{ml})$, B. venezuelans $(1.0 \mathrm{ml})$ and $B$. amyloliquefaciens $(1.0 \mathrm{ml})$ ] sourced from dumpsite soil. Total $5 \mathrm{ml}$ of inoculum $\left(2 \times 10^{9} \mathrm{CFU} \mathrm{ml}^{-1}\right)$ was sprayed on the feed stock material of each bin after mixing it with distill water in ratio $1: 5(\mathrm{v} / \mathrm{v})$. A slurry of $1 \mathrm{~kg}$ fresh cow dung diluted with distill water $(1: 100 \mathrm{w} / \mathrm{v})$ was added to bin $\mathrm{Cs}_{3}$ and $\mathrm{Cs}_{4}$. The four maintained MSW treatments were:

\section{Compost}

$\mathrm{Cs}_{1}$ (control), $15 \mathrm{~kg}$ MSW and bulking agents (1:7:6:0:0)—MSW only and no inoculation.

$\mathrm{Cs}_{2}, 15 \mathrm{~kg}$ MSW and bulking agents (1:7:6:1:0)—MSW and only inoculation of bacterial consortium.

$\mathrm{Cs}_{3}, 15 \mathrm{~kg}$ MSW and bulking agents (1:7:6:0:1)—MSW and only cow dung slurry.

$\mathrm{Cs}_{4}, 15 \mathrm{~kg}$ MSW and bulking agents (1:7:6:1:1)—MSW with both cow dung slurry and inoculation of bacterial consortium.
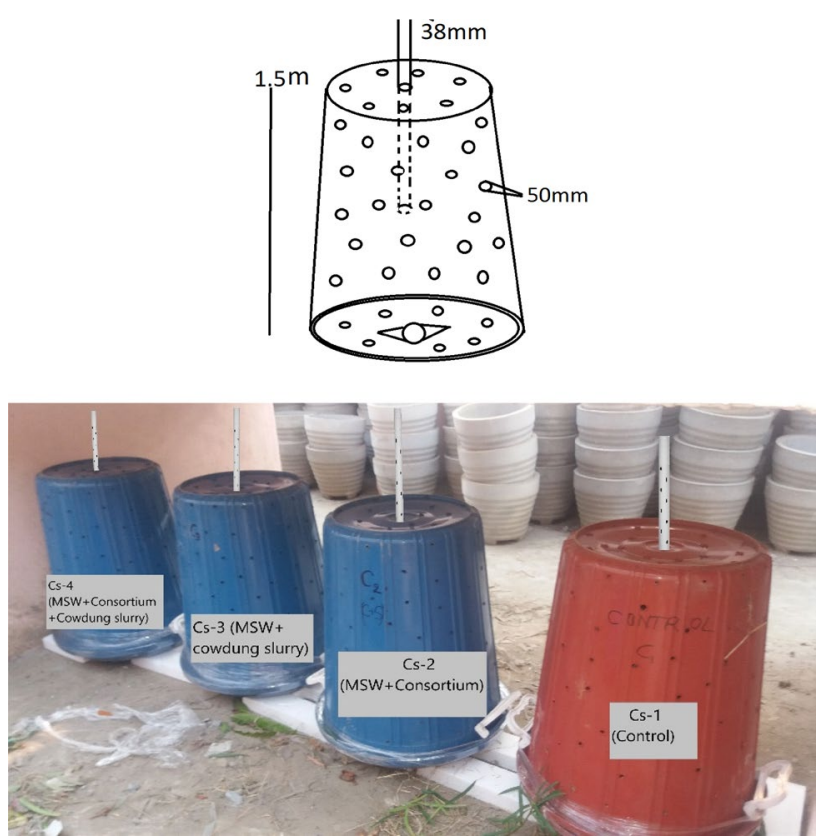

Fig. 1 Experimental setup of passive aerobic bin composting 
We maintained the same level of moisture content in all the treatments by adding requisite amount of water, in place of inoculum/cow dung slurry. The compost mixture was regularly turned to provide sufficient aeration and maintain the temperature. Sampling of the generated MSW compost was done at 15, 30, 60 and 90 days until the waste got stabilized. Temperature of the bin was monitored daily by a digital thermometer during MSW composting.

\section{Extraction of the humic substances}

Thirty grams of each compost sample was washed with distill water to flush the non-HS fraction. For extraction of HA, the washed compost samples were dried and sieved through a $2-\mathrm{mm}$ sieve. $2 \mathrm{~g}$ dried and sieved compost in a 250-ml Erlenmeyer flask with $40 \mathrm{ml}$ of $\mathrm{NaOH}(0.1 \mathrm{M})$ were extracted. The supernatant was centrifuged at $4000 \times g$ for 15 min and filtered through Whatman paper (no. 42). The precipitation of humic acids from the solution was proceeded by adding $1.5 \mathrm{M} \mathrm{H}_{2} \mathrm{SO}_{4}$ for $24 \mathrm{~h}$ at $4{ }^{\circ} \mathrm{C}$ (Serra-Wittling et al. 1996). The FA was extracted from the supernatant by reabsorption through $0.1 \mathrm{M} \mathrm{NaOH}$. Humic solutions were dialyzed against distilled water to eliminate the excess salts. Obtained humic solution was lyophilized by freeze-drying. The lyophilized humic acid (HA) was subjected to elemental and spectroscopic analysis to calculate the compost maturity parameters as described below.

\section{Elemental analysis}

Elemental analysis $(\mathrm{C}, \mathrm{H}, \mathrm{O}$, and $\mathrm{N})$ was done on freezedried (HA) samples of compost (0.5-1 mg) by an Elemental analyzer (Perkin-Elmer, 2400 Series).

\section{Spectroscopic analysis}

The HA samples (2 mg) of compost were dissolved in $0.05 \mathrm{M} \mathrm{NaHCO}_{3}$ and analyzed for UV-Vis spectra by measuring the absorbance (190-400 nm) in a 1-cm quartz cuvette using spectrophotometer (Thermoelecron make). $E_{4} / E_{6}$ ratio is an indicator of condensation in the humic molecules (Stevenson 1982 ) while $E_{2} / E_{3}$ ratio relates to the molecular size of the humic substances (Agren et al. 2008). The $E_{4} / E_{6}$ ratio is the ratio of absorbance at $465 \mathrm{~nm}$ and $665 \mathrm{~nm}$ and $E_{2} / E_{3}$ ratio is the absorbance ratio at 265 and $365 \mathrm{~nm}$ (Chen et al. 1977).

The maturity indices were determined using the following methods:

(a) Humification ( $\Delta \log K$ coefficient), $\Delta \log K=\log$ $A_{400}-\log A_{600}$ (Fong et al. 2006). (b) Humification index $(\mathrm{HI})=$ " $C_{\mathrm{HA}} / C_{\mathrm{FA}}$ " or " $C_{\mathrm{FA}} / C_{\mathrm{HA}}$ " (Jimenez and Garcia 1992); (where HA is humic acid and FA is fulvic acid).

(c) Humification degree $(\mathrm{HD} \%)=\left(C_{\mathrm{THM}} / C_{\mathrm{HU}}\right) \times 100$ (DeNobili et al. 1986); (where $C_{\mathrm{THM}}$ is carbon of total humic matter and $C_{\mathrm{HU}}$ is carbon of humin).

\section{HA-FTIR spectroscopy}

A homogenized mixture of freeze-dried HA sample of MSW compost $(2 \mathrm{mg}$ ) and $200 \mathrm{mg} \mathrm{KBr}$ (FTIR grade) was prepared. The $\mathrm{KBr}$ pellets were pressed under vacuum over the $4000-400 \mathrm{~cm}^{-1}$ range at $0.5 \mathrm{~cm} \mathrm{~s}^{-1}$ (Smidt and Meissl 2007). Infrared spectra were recorded on a FTIR spectrophotometer (Perkin-Elmer, 2000). The average (50 scans) for each spectrum was recorded with correction against the ambient air. The mean values were estimated from the triplicate readings.

Statistical analyses were carried out by SPSS- 23.0 on the averages of $n=3 \pm$ standard deviations. The quantification of the maturity parameters was done at $P$ level of 0.01 or 0.05 of standard deviation (SD).

\section{Results and discussion}

\section{Humic substances}

\section{Elemental analysis}

The atomic $\mathrm{O} / \mathrm{C}, \mathrm{C} / \mathrm{H}$, and $\mathrm{C} / \mathrm{N}$ ratios are often used to monitor structural changes of HS (Adani et al. 2006). A decline in the $\mathrm{C} / \mathrm{N}$ and $\mathrm{O} / \mathrm{C}$ ratios in all the MSW treatments, $\mathrm{Cs}_{1}, \mathrm{Cs}_{2}$, $\mathrm{Cs}_{3}$, and $\mathrm{Cs}_{4}$ was observed (Table 1). The decreased $\mathrm{C}$ percentage was ascribed to the substitutions of aliphatic chains by aromatics and evolution of carbon dioxide, whereas $\mathrm{O}$ (oxygen) percentage increased due to enhanced oxidation process (Senesi and Brunetti 1996). The N percentage increased for all treatments, being maximum for $\mathrm{Cs}_{4}$ at $3.1 \%$ $(P<0.05)$. The additive, cow dung slurry enriched with carbon and nitrogen, might have played its role (Adegunloye et al. 2007). Cow dung possessed a desirable $\mathrm{C} / \mathrm{N}$ ratio (19) that resulted in better microbial proliferation. Intensified microbial activity with faster molecular reorganization process resulted in higher condensation of the aromatic compounds. Xiaowei et al. (2011) reported similar increased N percentage (from 4.12 to $5.37 \%$ ) during the co-composting of sewage sludge and cow dung. The $\mathrm{C} / \mathrm{H}$ ratio increased for all the MSW treatments during composting. Overall, the highest $\mathrm{C} / \mathrm{H}$ ratio $(0.9 \%)$ was observed in the treatment $\mathrm{Cs}_{4}$, ascribed to the fastest organic material decomposition in the treatment during composting. 


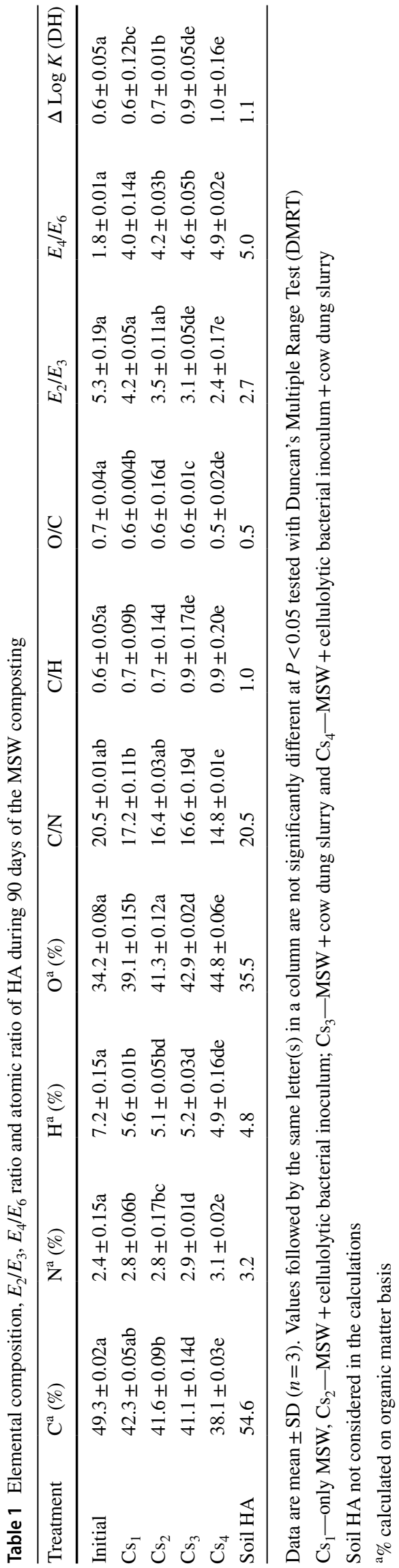

The $E_{4} / E_{6}$ and $E_{2} / E_{3}$ ratios during composting reflect the quality and molecular size of the HAs (Albrecht et al. 2011). The results (Table 1 ) show an increased $E_{4} / E_{6}$ ratio for all MSW treatments at 90 days of composting. Overall, treatment $\mathrm{Cs}_{4}$ reflected higher aromaticity with maximum value for $E_{4} / E_{6}$ ratio $(1.8-4.9 ; P<0.01)$ (Boguta et al. 2016). The observed $E_{4} / E_{6}$ ratio for HAs in all MSW treatments (4.0, 4.2, 4.6, and 4.9) is closer to the prescribed limit, 5 (Chen et al. 1977). This reveals the dominance of HAs in the compost samples (Zbytniewski and Buszewski 2005). Sharma et al. (2014) observed an increased $E_{4} / E_{6}$ ratio (4.29-7.71) with additive EMs (effective microorganisms) inoculation at 60 days of composting. Likewise, Sarika et al. (2014) reported an $E_{4} / E_{6}$ ratio within 2.6-5.6 in a rotatory drum composting. The $E_{2} / E_{3}$ ratio for the MSW treatments $\left(\mathrm{Cs}_{1}\right.$, $\mathrm{Cs}_{2}, \mathrm{Cs}_{3}$, and $\mathrm{Cs}_{4}$ ) reduced from 5.3 to $4.2,3.5,3.1$, and 2.4 $(P<0.01)$. De Campos et al. (2017) achieved a decreased $E_{2} / E_{3}$ ratio being 4.3 to 3.3 after 210 days of composting.

The Humification Index (HI) is a reliable parameter to test compost maturity (Jimenez and Garcia 1992). HI was evaluated as the ratio of the $C_{\mathrm{HA}} / C_{\mathrm{FA}}$ fractions (non-humified to humified organic carbon) in the compost. HI values ranging within 1.6 and 1.9 indicated well humified and mature compost (Francou et al. 2003). In our study, the HI values increased [0.6-1.2, 1.9, 2.3, and $2.8(P<0.05)]$ for all the treatments $\mathrm{Cs}_{1}, \mathrm{Cs}_{2}, \mathrm{Cs}_{3}$, and $\mathrm{Cs}_{4}$ (Table 2). Chefetz et al. (1996) registered increased HI values (0.91-3.0) at the end of MSW composting. This indicated maturity of generated MSW compost and its suitability for application to agricultural purposes (Raj and Antil 2011).

The Degree of Humification (DH) adds to the information about the maturity of compost (Tomati et al. 2000). In case of MSW, the standard range for $\mathrm{DH}(\Delta \log K$ coefficient) comprises of three categories for the HAs. It includes categories A, B and $\mathrm{C}$ with values <0.6, 0.6-0.8 and 0.8-1.1 (Fong et al. 2006). In study, values for DH in the treatments $\mathrm{Cs}_{1}, \mathrm{Cs}_{2}, \mathrm{Cs}_{3}$, and $\mathrm{Cs}_{4}$ were found within 0.6 and 1.0 (Table 1). The observed value for $\Delta \log K$ coefficient (DH) was highest in the EM and cow dung slurry amended treatment, $\mathrm{Cs}_{4}$. It ascribes to the enhanced humification due to diverse microbiota and more nutrient availability.

Humification Degree (HD\%) is another parameter to verify compost stability. Ciavatta et al. (2001) reported HD greater than $70 \%$ indicating a well humified and mature product. In this study, the achieved HD for treated composts ordered as follows; $\mathrm{Cs}_{4}>\mathrm{Cs}_{3}>\mathrm{Cs}_{2}(82.4 \%, 77.8 \%$, and $76.4 \%)$ compared to control, $\mathrm{Cs}_{1}(60 \%)$. The results reflect that EMs and/or cow dung might have intensified the waste humification rate (Song et al. 2014).

The ratio of $C_{\mathrm{FA}}$ (fulvic acid) to $C_{\mathrm{HA}}$ (humic acid) defines the quality of a compost (Table 2). Throughout the study, we observed increased $C_{\mathrm{HA}}$ values, whereas in case of $C_{\mathrm{FA}}$ values a decreased trend for all treatments $\left(\mathrm{Cs}_{1}, \mathrm{Cs}_{2}, \mathrm{Cs}_{3}\right.$, 
Table $2 C_{\mathrm{HA}}-C_{\mathrm{FA}}$ values, Humification Index (HI) and Degree of Humification (DH) during 90 days of the MSW composting

\begin{tabular}{llllll}
\hline Treatments & $C_{\mathrm{HA}}(\%)$ & $C_{\mathrm{FA}}(\%)$ & $C_{\mathrm{FA}} / C_{\mathrm{HA}}$ & $\mathrm{HI}\left(C_{\mathrm{HA}} / C_{\mathrm{FA}}\right)$ & $\mathrm{HD}(\%)$ \\
\hline Initial & $2.3 \pm 0.17 \mathrm{a}$ & $3.9 \pm 0.11 \mathrm{a}$ & $1.7 \pm 0.08 \mathrm{~b}$ & $0.6 \pm 0.03 \mathrm{~b}$ & $20.4 \pm 0.11 \mathrm{a}$ \\
$\mathrm{Cs}_{1}$ & $3.5 \pm 0.12 \mathrm{bc}$ & $2.9 \pm 0.05 \mathrm{abd}$ & $0.8 \pm 0.12 \mathrm{~b}$ & $1.2 \pm 0.03 \mathrm{~b}$ & $60.0 \pm 0.09 \mathrm{~b}$ \\
$\mathrm{Cs}_{2}$ & $4.8 \pm 0.07 \mathrm{~d}$ & $2.6 \pm 0.21 \mathrm{~b}$ & $0.5 \pm 0.04 \mathrm{ad}$ & $1.9 \pm 0.13 \mathrm{~b}$ & $76.4 \pm 0.02 \mathrm{c}$ \\
$\mathrm{Cs}_{3}$ & $5.6 \pm 0.01 \mathrm{~d}$ & $2.4 \pm 0.19 \mathrm{~cd}$ & $0.4 \pm 0.26 \mathrm{e}$ & $2.3 \pm 0.09 \mathrm{~cd}$ & $77.8 \pm 0.16 \mathrm{~d}$ \\
$\mathrm{Cs}_{4}$ & $6.1 \pm 0.15 \mathrm{a}$ & $2.2 \pm 0.27 \mathrm{e}$ & $0.4 \pm 0.06 \mathrm{de}$ & $2.8 \pm 0.05 \mathrm{e}$ & $82.4 \pm 0.03 \mathrm{e}$ \\
\hline
\end{tabular}

Data are mean $\pm \mathrm{SD}(n=3)$. Values followed by the same letter(s) in a column are not significantly different at $P<0.05$ tested with Duncan's Multiple Range Test (DMRT)

$\mathrm{Cs}_{1}$-only MSW, $\mathrm{Cs}_{2}-\mathrm{MSW}+$ cellulolytic bacterial inoculum; $\mathrm{Cs}_{3}-\mathrm{MSW}+$ cow dung slurry and $\mathrm{Cs}_{4}-$ MSW + cellulolytic bacterial inoculum + cow dung slurry and $\mathrm{Cs}_{4}$ ) was reported. MSW treatment $\mathrm{Cs}_{4}$ showed maximum increase in $C_{\mathrm{HA}}(2.3 \%$ to $6.1 \%)$, at 90 days of composting. This is ascribed to larger loss of aliphatic groups, with compost maturity (Senesi and Brunetti 1996). Chefetz et al. (1996) reported increased $C_{\mathrm{HA}}$ values from 7 to $12 \%$ in the mature compost, prepared from MSW. Huang et al. (2006) observed a similar increase in the $C_{\mathrm{HA}}$ values from 2.05 to $3.79 \%$ throughout 63 days of composting. During MSW composting, the values of $C_{\mathrm{FA}}$ decreased for all the treatments at 90 days. The observed value of $C_{\mathrm{FA}}$ was the least for $\mathrm{Cs}_{4}$ treatment (2.2\%) followed by $\mathrm{Cs}_{3}, \mathrm{Cs}_{2}$, and $\mathrm{Cs}_{1}$ $(2.4 \%, 2.6 \%$, and $2.9 \%)$ on Day 90 of composting. Barje et al. (2013) observed a similar trend for $C_{\mathrm{FA}}$ values throughout MSW composting. This confirmed the role of additives, EM's and cow dung in enhanced stability of compost.

\section{Correlation analysis among the humification indices}

The $\Delta \log K$ coefficient positively correlated $(P<0.05$; $P<0.01)$ with all the maturity indices in Table 3 . A positive correlation between $E_{4} / E_{6}$ ratio $(r=0.965, P<0.05)$ and
$\Delta \log K$ coefficient indicated good humification. The results favor aggregation of the molecules and increased degradation of aliphatic structures. Temperature shows a significant negative correlation with $E_{4} / E_{6}$ ratio $(r=0.998, P<0.05)$ and $\Delta \log K$ coefficient $(r=0.979, P<0.05)$. This implies a negative influence of the decreased temperature on the humification indices. In addition, $\Delta \log K$ coefficient positively correlated $(r=0.936, P<0.01)$ with the atomic $\mathrm{C} / \mathrm{H}$ ratio. These statistical observations reconfirm the role of commixture (EM and cow dung) in accelerating the waste degradation process.

\section{UV-Vis spectroscopic analysis}

Three major peaks were noticed in MSW treatments, $\mathrm{Cs}_{1}$, $\mathrm{Cs}_{2}, \mathrm{Cs}_{3}$ and $\mathrm{Cs}_{4}$ (Fig. 2). A peak exhibited near 205-210 nm shifted to $215 \mathrm{~nm}, 220 \mathrm{~nm}, 225 \mathrm{~nm}$ and $220 \mathrm{~nm}$ during MSW composting. This shift in peaks is due to the increased content of inorganic nitrogen. The MSW treatment, $\mathrm{Cs}_{4}$ with EM and cow dung slurry shows the highest protein degradation. Li et al. (2014) reported similar increase in the values from

Table 3 Correlation between elemental composition, $E_{2} / E_{3}, E_{4} / E_{6}$ ratios, atomic ratios, $\Delta \log K$ of HA and temperature during 90 days of the MSW composting

\begin{tabular}{|c|c|c|c|c|c|c|c|c|c|c|c|}
\hline & $\mathrm{C}(\%)$ & $\mathrm{N}(\%)$ & $\mathrm{H}(\%)$ & $\mathrm{O}(\%)$ & $\mathrm{C} / \mathrm{N}$ & $\mathrm{C} / \mathrm{H}$ & $\mathrm{O} / \mathrm{C}$ & $E_{2} / E_{3}$ & $E_{4} / E_{6}$ & $\Delta \log K$ & Temperature \\
\hline $\mathrm{C}(\%)$ & 1.000 & & & & & & & & & & \\
\hline $\mathrm{N}(\%)$ & $-0.991^{*}$ & 1.000 & & & & & & & & & \\
\hline $\mathrm{H}(\%)$ & $0.970^{*}$ & $-0.937 * *$ & 1 & & & & & & & & \\
\hline $\mathrm{O}(\%)$ & $-0.971^{*}$ & $0.974 *$ & $-0.956^{* *}$ & 1 & & & & & & & \\
\hline $\mathrm{C} / \mathrm{N}$ & $0.993 *$ & $-0.982 *$ & $0.960 *$ & $-0.972 *$ & 1 & & & & & & \\
\hline $\mathrm{C} / \mathrm{H}$ & $-0.891 * *$ & $0.902 * *$ & $-0.900 * *$ & $0.972 *$ & -0.889 & 1 & & & & & \\
\hline $\mathrm{O} / \mathrm{C}$ & $0.957 * *$ & $-0.971^{*}$ & $0.863^{\text {ns }}$ & $-0.919 * *$ & $0.967^{*}$ & $-0.813^{\mathrm{ns}}$ & 1 & & & & \\
\hline$E_{2} / E_{3}$ & $0.965^{*}$ & $-0.971 *$ & $0.935 * *$ & $-0.995^{*}$ & $0.976^{*}$ & $-0.960 *$ & $0.938 * *$ & 1 & & & \\
\hline$E_{4} / E_{6}$ & $-0.986^{*}$ & $0.960 *$ & $-0.991 * *$ & $0.949 * *$ & $-0.968^{*}$ & $0.873^{\mathrm{ns}}$ & $-0.897 * *$ & $-0.929 * *$ & 1 & & \\
\hline$\Delta \log K$ & $-0.983^{*}$ & $0.970 *$ & $-0.973 *$ & $0.989 * *$ & $-0.991 *$ & $0.936 * *$ & $-0.933 * *$ & $-0.989 *$ & $0.965^{*}$ & 1 & \\
\hline Temperature & $0.992 *$ & $-0.971^{*}$ & $0.992 *$ & $-0.965^{*}$ & $0.980 *$ & $-0.893 * *$ & $0.915^{*}$ & $0.950 *$ & $-0.998 *$ & $-0.979 *$ & 1 \\
\hline
\end{tabular}

*Correlation is significant at the 0.05 level (two tailed), **correlation is significant at the 0.01 level (two tailed), $n s$ not significant ANOVA $-F(4,1)=0.007 ; P<0.01 ; P<0.05 ; R^{2}=0.9999 ; 99 \%$ significant 


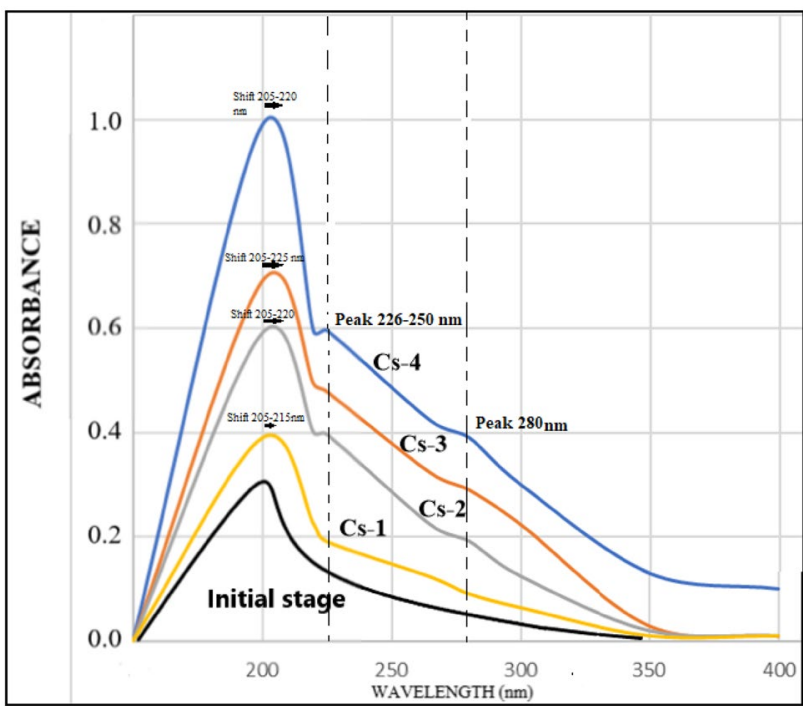

Fig. 2 HA-UV spectra at the initial and final stages of MSW composting

0.927 to $6.127 \mathrm{~nm}$ in absorption peaks at $200-226 \mathrm{~nm}$. The spectrum range between 226 and $250 \mathrm{~nm}$ reflects stability of the organic matter (Vieyra et al. 2009). The unsaturated $\pi-\pi^{*}$ transition related to the polar functional groups define the spectrum. The peak near $226 \mathrm{~nm}$ represents an increased value for the MSW treatments, $\mathrm{Cs}_{1}, \mathrm{Cs}_{2}, \mathrm{Cs}_{3}$ and $\mathrm{Cs}_{4}$ at 0.19 , $0.4,0.49$ and 0.61 . The third peak at $280 \mathrm{~nm}$ is related to the size, aromaticity and humification of the molecules. In our study, we observed an increased value for treatments $\mathrm{Cs}_{3}$ $(0.4)$ and $\mathrm{Cs}_{4}(0.31)$ at $280 \mathrm{~nm}$ in 90 days during composting. Li et al. (2010) reported an increase from 0.008 to 0.03 at $\mathrm{SUVA}_{280}$ as composting proceeded with time.

Infrared spectroscopy is a qualitative tool to analyze the chemistry of HA complexes. The band patterns exemplified the complex interactions between the degrading molecules (Smidt 2011). In our study, the MSW treatments $\left(\mathrm{Cs}_{1}, \mathrm{Cs}_{2}\right.$, $\mathrm{Cs}_{3}$ and $\mathrm{Cs}_{4}$ ) show broad absorption bands for the extracted HA (Fig. 3). A strong absorption peak at $3400 \mathrm{~cm}^{-1}(\mathrm{O}-\mathrm{H}$ stretching) confirmed the presence of $\mathrm{OH}$ and amino groups. Absorption peak observed at $2920 \mathrm{~cm}^{-1}$ (C-H stretching) relates to aliphatic methylene groups. This constant band region $\left(2920 \mathrm{~cm}^{-1}\right)$ confirms stabilization of organic matter during composting. Two disproportional bands at 2520 and $1800 \mathrm{~cm}^{-1}$ were assigned to carbonate addition. Peaks observed at 1740,1650 and $1425 \mathrm{~cm}^{-1}(\mathrm{C}=\mathrm{O}$ stretching) were due to generation of metabolites.

The decrease in polysaccharides was visible by peaks at 1160,1060 and $1030 \mathrm{~cm}^{-1}$ (C-O stretching). At last, few disproportional peaks at $3695 \mathrm{~cm}^{-1}, 1060 \mathrm{~cm}^{-1}$, and $1030 \mathrm{~cm}^{-1}$ impute clay minerals (Smidt et al. 2008). All the MSW compost treatments depicted similar FTIR spectra for HA. Certain absorption peaks indicated variable structures

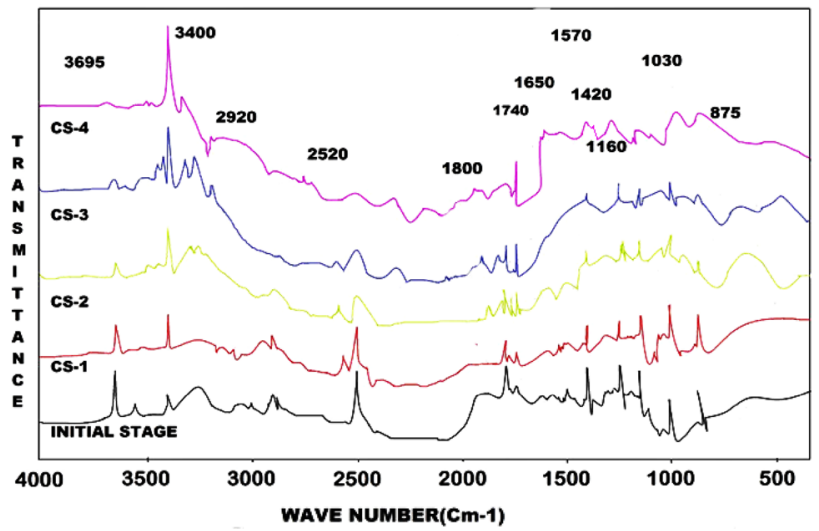

Fig. 3 HA-FTIR spectra at the initial and final stages of MSW composting

with different number of functional groups. A peculiar peak $\left(1384 \mathrm{~cm}^{-1}\right)$ in the MSW treatment $\mathrm{Cs}_{4}$ explains evolution of nitrates due to $\mathrm{N}-\mathrm{O}$ stretch. EM and cow dung slurry also endorsed the condensation process for nitrate production. Figure 3. HA-FTIR spectra at the initial and final stages of MSW composting.

A relative intensity ratio of the absorption bands defines the HA spectra. During MSW composting, the absorption ratio $(2920 / 1650)$ decreased from 0.81 to 0.75 for treatment $\mathrm{Cs}_{3}$. The absorption ratio (2920/1650) was lowest (0.61-0.56) for EM and cow dung slurry amended treatment $\left(\mathrm{Cs}_{4}\right)$ after 90 days. This was due to higher degradation of the aliphatic compounds. Sarika et al. (2014) reported a decreased absorption ratio from 0.82 to 0.78 and $0.96-0.93$ in a rotary drum composting. The aromatic $\mathrm{C} /$ poly $\mathrm{C}$ ratio (1650/1160) increased from 5.9 to 6.8, 6.3-7.5, and 6.9-7.8 in MSW treatments $\mathrm{Cs}_{2}, \mathrm{Cs}_{3}$ and $\mathrm{Cs}_{4}$. The reduced polysaccharides supplemented energy to the microbes throughout composting. This led to an increase in the concentration of aromatics (Zhou et al. 2014). It is suggestive of an enhanced degradation of aliphatic compounds due to EM and cow dung slurry. Results from the study of humic substances verify the stability and maturity of MSW compost. Wei et al. (2007) reported similar findings in the extracted fractions of HS during MSW composting.

\section{Temperature}

In this study, a decline in temperature was observed between Day 0 and Day 15 during MSW composting (Fig. 4). The temperature of all the treatments subsequently increased between Day 15 and Day 30 (mesophilic phase). This increase continued until Day 45 (thermophilic stage) during MSW composting. A reduction in temperature during maturation (Day 90) exhibited a typical biodegradation curve. The attained temperature was highest for the $\mathrm{Cs}_{4}$ treatment 


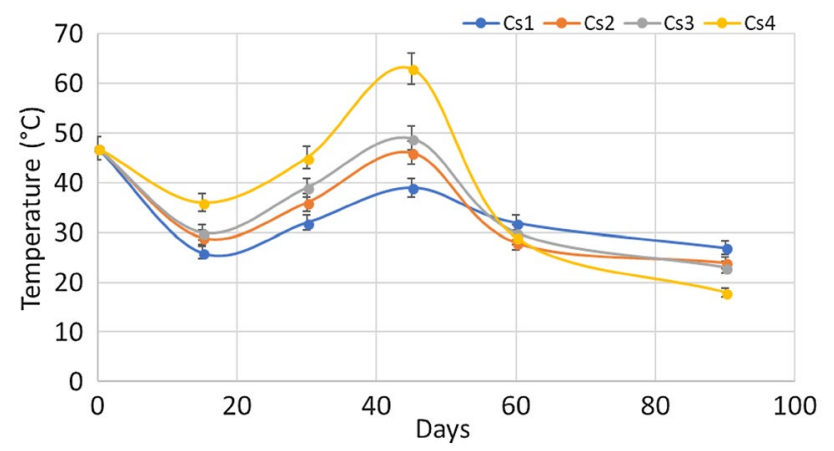

Fig. 4 Changes in temperature in MSW treatment piles during 90 days of composting

$\left(63{ }^{\circ} \mathrm{C}\right.$ ) followed by $\mathrm{Cs}_{3}, \mathrm{Cs}_{2}$, and $\mathrm{Cs}_{1}\left(49{ }^{\circ} \mathrm{C}, 46{ }^{\circ} \mathrm{C}\right.$, and $39^{\circ} \mathrm{C}$, respectively) by Day 45 . This temperature increase is ascribed to the oxidation reactions caused by thermophilic microbes. The microbiota increased the degradation rate, releasing more heat (Singh and Kalamdhad 2015). At the end of composting (maturation phase), the temperature ranged from 18 to $27^{\circ} \mathrm{C}$. In this study, the temperature settled above $55{ }^{\circ} \mathrm{C}$ in the thermophilic phase (Day 45) of composting. This confirms a good sanitation degree for the generated compost (Barren et al. 2006).

\section{Conclusion}

Elemental analysis, UV and FTIR spectra of the humic fractions showed early maturity for MSW composting, with additives. The commixture of EM and cow dung derived better stability in MSW compost, over other inoculated and non-inoculated treatments. Above study also identified the role of temperature in intensified microbial activity and accelerated compost maturation. This research could provide a useful theoretical and practical foundation for small-scale MSW composting in India.

Open Access This article is distributed under the terms of the Creative Commons Attribution 4.0 International License (http://creativecommons.org/licenses/by/4.0/), which permits unrestricted use, distribution, and reproduction in any medium, provided you give appropriate credit to the original author(s) and the source, provide a link to the Creative Commons license, and indicate if changes were made.

\section{References}

Adani F, Ricca G, Tambone F, Genevini P (2006) Isolation of the stable fraction (the core) of humic acids. Chemosphere 65:1300-1307. https://doi.org/10.1016/j.chemosphere.2006.04.032
Adegunloye DV, Adetuyi FC, Akinosoye FA, Doyeni MO (2007) Microbial analysis of compost using cowdung as booster. Pak J Nutr 13(5):506-510

Agren A, Buffam I, Berggren M, Bishop K, Jansson M, Laudon H (2008) Dissolved organic carbon characteristics in boreal streams in a forest-wetland gradient during the transition between winter and summer. J Geophys Res Biogeosci 113:G03012. https://doi. org/10.1029/2007JG000674

Albrecht R, Petit JL, Terrom G, Perissol C (2011) Comparison between UV spectroscopy and NIRS to assess humification process during sewage sludge and green wastes co-composting. Bioresour Technol 102(6):4495-4500. https://doi.org/10.1016/j.biort ech.2010.12.053

Annepu RK (2012) Report on sustainable solid waste management in India. Waste-to-Energy Research and Technology Council (WTERT), pp 1-189. Accessed 10 Nov 2017

Barje F, El Fels L, El Hajjouji H, Winterton P, Hafidi M (2013) Biodegradation of organic compounds during co-composting of olive oil mill waste and municipal solid waste with added rock phosphate. Environ Technol 34(21):2965-2975. https://doi. org/10.1080/09593330.2013.796009

Barren R, Pagans E, Faltys G, Sanchez A (2006) Effect of inoculation dosing on the composting of source-selected organic fraction of municipal solid wastes. J Chem Technol Biotechnol 81:420-425. https://doi.org/10.1002/jctb.1418

Boguta P, Pieczywek PM, Sokołowska Z (2016) A comparative study of the application of fluorescence excitation-emission matrices combined with parallel factor analysis and nonnegative matrix factorization in the analysis of $\mathrm{Zn}$ complexation by humic acids. Sensors 16(10):1760. https://doi.org/10.3390/s16101760

Chefetz B, Hatcher P, Hadar Y, Chen Y (1996) Chemical and biological characterization of organic matter during composting of municipal solid waste. J Environ Qual 25:776-785. https://doi.org/10.2134/ jeq1996.00472425002500040018x

Chen Y, Senesi N, Schnitzer M (1977) Information provided on humic substances by $E_{4} / E_{6}$ ratios. Soil Sci Soc Am J 41:352-358. https ://doi.org/10.2136/sssaj1977.03615995004100020037x

Ciavatta C, Francioso O, Montecchio D, Cavani L, Grigatti M (2001) Use of organic wastes of agro industrial and municipal origin for soil fertilisation: quality criteria for organic matter. In: The first international encounter, management of organic wastes in rural Mediterranean areas, Pamplona, 22-23 Feb. University of Navarra, pp 1-17

De Campos SX, Zittel R, da Cunha KM, Colares LG (2017) Home composting using facultative reactor in solid waste management in rural areas. InTech. 10.5772/intechopen.69429

DeNobili M, Petrussi F (1988) Humification index (HI) as evaluation of the stabilization degree during composting. J Ferment Technol 66(5):577-583. https://doi.org/10.1016/0385-6380(88)90091-X

DeNobili M, Cercignani G, Leita L, Sequi P (1986) Evaluation of organic matter stabilization in sewage sludge. Commun Soil Sci Plant 17(10):1109-1119. https://doi.org/10.1080/0010362860 9367777

Fong SS, Lau IL, Chong WN, Asking J, Faizal M, Nor M, Satirawaty A, Pauzan M (2006) Characterization of the coal derived humic acids from Mukah, Sarawak as soil conditioner. J Braz Chem Soc 17(3):582-587. https://doi.org/10.1590/S0103-505320060003000 23

Francou C, Poitrenaud M, Hoot S (2003) Stabilization of organic matter during composting: influence of process and feedstocks. Compost Sci Util 13(1):72-83. https://doi.org/10.1080/10656 57X.2005.10702220

Huang GF, Wu QT, Wong JW, Nagar BB (2006) Transformation of organic matter during co-composting of pig manure with sawdust. Bioresour Technol 97(15):1834-1842. https://doi.org/10.1016/j. biortech.2005.08.024 
Jimenez EI, Garcia VP (1992) Determination of maturity indices for city refuse composts. Agric Ecosyst Environ 38(4):331-343. https ://doi.org/10.1016/0167-8809(92)90154-4

Joshi R, Ahmed S (2016) Status and challenges of municipal solid waste management in India: a review. Cogent Environ Sci 2(1):1139434. https://doi.org/10.1080/23311843.2016.1139434

Leal OD, Castilhos RM, Pauletto EA, Pinto LF, Pillon CN, Penning LH, Santos DC (2015) Organic matter fractions and quality of the surface layer of a constructed and vegetated soil after coal mining I-humic substances and chemical characterization. Rev Bras Cienc Solo 39(3):886-894. https://doi.org/10.1590/01000 683 rbcs20140783

Li Y, Yue Q, Gao B (2010) Adsorption kinetics and desorption of $\mathrm{Cu}$ (II) and $\mathrm{Zn}$ (II) from aqueous solution onto humic acid. J Hazard Mater 178(1-3):455-461. https://doi.org/10.1016/j.jhazm at.2010.01.103

Li D, He XS, Xi BD, Wei ZM, Pan HW, Cui DY (2014) Study on UV-visible spectra characteristic of dissolved organic matter during municipal solid waste composting. In: Selected proceedings of the eighth international conference on waste management and technology. Trans Tech Publications Ltd, Stafa-Zurich. https:// pdfs.semanticscholar.org/1bec/c3a41b28ffeb4566a5b5ce9a6202a9 0816c4.pdf

Mahar B, Liu J, Li H, Nye Y (2009) Bio-pretreatment of municipal solid waste prior to landfilling and its kinetics Rasool. Biodegradation 20:319-330. https://doi.org/10.1007/s10532-008-9222-2

Manu MK, Kumar R, Garg A (2016) Drum composting of food waste: a kinetic study. Procedia Environ Sci 35:456-463. https://doi. org/10.1016/j.proenv.2016.07.029

Nakasaki K, Hirai H (2017) Temperature control strategy to enhance the activity of yeast inoculated into compost raw material for accelerated composting. Waste Manag 65:29-36. https://doi. org/10.1016/j.wasman.2017.04.019

Pare T, Dinel H, Schnitzer M, Dumontet S (1998) Transformations of carbon and nitrogen during composting of animal manure and shredded paper. Biol Fertil Soils 26(3):173-178. https://doi. org/10.1007/s003740050364

Raj D, Antil RS (2011) Evaluation of maturity and stability parameters of composts prepared from agro industrial wastes. Bioresour Technol 102:2868-2873. https://doi.org/10.1016/j.biort ech.2010.10.077

Rastogi M, Nandal M (2018) Composting an emerging technology for solid waste management in India. Handbook of research on microbial tools for environmental waste management. IGI Global, pp 105-126. https://doi.org/10.4018/978-1-5225-3540-9.ch006

Sarika D, Singh J, Prasad R, Vishan I, Varma VS, Kalamdhad AS (2014) Study of physico-chemical and biochemical parameters during rotary drum composting of water hyacinth. Int J Recycle Org Waste 3(3):9. https://doi.org/10.1007/s40093-014-0063-1

Scotti R, Bonanomi G, Scelza R, Zoina A, Rao MA (2015) Organic amendments as sustainable tool to recovery fertility in intensive agricultural systems. J Soil Sci Plant Nutr 15(2):333-352. https ://doi.org/10.4067/S0718-95162015005000031

Senesi N, Brunetti G (1996) Chemical and physicochemical parameters for quality evaluation of humic substances produced during composting. In: De Bertoldi M, Sequi P, Lemmes B, Papi T (eds) The science of composting, Part 1. Blackie, Glasgow, pp 195-212

Serra-Wittling C, Barriuso E, Houot S (1996) Impact of composting type on composts organic matter characteristics. In: de Bertoldi $\mathrm{M}$ et al (eds) The science of composting. Blackie, Bologne, pp 262-273

Sharma A, Sharma R, Arora A, Shah R, Singh A, Pranaw K, Nain L (2014) Insights into rapid composting of paddy straw augmented with efficient microorganism consortium. Int J Recycle Org Waste 3(2):54. https://doi.org/10.1007/s40093-014-0054-2

Singh J, Kalamdhad AS (2015) Assessment of compost quality in agitated pile composting of water hyacinth collected from different sources. Int J Recycle Org Waste 4(3):175-183. https://doi. org/10.1007/s40093-015-0097-z

Smidt BC (2011) Fundamentals of Fourier transform infrared spectroscopy, 2nd edn. CRC Press, Boca Raton

Smidt E, Meissl K (2007) The applicability of Fourier Transform Infrared (FT-IR) spectroscopy in waste management. Waste Manag 27:268-276. https://doi.org/10.1016/j.wasman.2006.01.016

Smidt E, Tintner J, Meissl K, Binner E (2008) Influence of input materials and composting operation on humification of organic matter. Dyn Soil Dyn Plant 2(Special Issue 1):50-590. http://www.globa lsciencebooks.info/Online/GSB

Song C, Li M, Jia X, Wei Z, Zhao Y, Xi B, Zhu C, Liu D (2014) Comparison of bacterial community structure and dynamics during the thermophilic composting of different types of solid wastes: anaerobic digestion residue, pig manure and chicken manure. Microb Biotechnol 5:424-433. https://doi.org/10.1111/1751-7915.12131

Stevenson FJ (1982) Humus chemistry. Wiley, New York

Tomati U, Madejon E, Galli E (2000) Evolution of humic acid molecular weight as an index of compost stability. Compost Sci Util 8(2):108-115. https://doi.org/10.1080/1065657X.2000.10701756

Varma VS, Das S, Sastri CV, Kalamdhad AS (2017) Microbial degradation of lignocellulosic fractions during drum composting of mixed organic waste. Sustain Environ Res 27(6):265-272. https ://doi.org/10.1016/j.serj.2017.05.004

Vieyra FEM, Palazzi VI, Sanchez de Pinto MI, Borsarelli CD (2009) Combined UV-Vis absorbance and fluorescence properties of extracted humic substances-like for characterization of composting evolution of domestic solid wastes. Geoderma 151(3-4):6167. https://doi.org/10.1016/j.geoderma.2009.03.006

Voberkova S, Vaverkoa MD, Buresova A, Adamcova D, Vrsansks M, Kynicky J, Brtnicky M, Adam V (2017) Effect of inoculation with white-rot fungi and fungal consortium on the composting efficiency of municipal solid waste. Waste Manag 61:157-164. https ://doi.org/10.1016/j.wasman.2016.12.039

Wei Z, Xi B, Zhao Y, Wang S, Liu H, Jiang Y (2007) Effect of inoculating microbes in municipal solid waste composting on characteristics of humic acid. Chemosphere 68(2):368-374. https://doi. org/10.1016/j.chemosphere.2006.12.067

Xiaowei L, Meiyan X, Jian Y, Zhiding H (2011) Compositional and functional features of humic acid-like fraction from vermicomposting of sewage sludge and cow dung. J Hazard Mater 1185:740-748. https://doi.org/10.1016/j.jhazmat.2010.09.08

Zbytniewski R, Buszewski B (2005) Characterization of natural organic matter (NOM) derived from sewage sludge compost. Part 2: multivariate techniques in the study of compost maturation. Bioresour Technol 96(4):479-484. https://doi.org/10.1016/j.biort ech.2004.05.019

Zhou Y, Selvam A, Wong JW (2014) Evaluation of humic substances during co-composting of food waste, sawdust and Chinese medicinal herbal residues. Bioresour Technol 168:229-234. https://doi. org/10.1016/j.biortech.2014.05.070

Publisher's Note Springer Nature remains neutral with regard to jurisdictional claims in published maps and institutional affiliations. 